\title{
GAYA BAHASA, TEKNIK PENERJEMAHAN, DAN KUALITAS TERJEMAHAN DALAM DONGENG DISNEY DWIBAHASA BERJUDUL CINDERELLA: MY BEDTIME STORY DAN TINKERBELL AND THE GREAT FAIRY RESCUE
}

\author{
Yogi Rohana ${ }^{1}$; Riyadi Santosa ${ }^{2}$ Djatmika $^{3}$ \\ 1,2,3 Universitas Sebelas Maret, Surakarta \\ yogihana6@gmail.com
}

\begin{abstract}
ABSTRAK
Penerjemah mulai membidik kegiatan menerjemahkan berbagai genre literatur anak, salah satunya adalah dongeng. Meskipun teks dongeng anak memiliki fitur bahasa yang sederhana, akan tetapi proses penerjemahannya tidak bisa dianggap sepele. Penerjemah harus memperhatikan karakteristik dan kemampuan kebahasaan anak sesuai usianya. Penelitian ini bertujuan untuk mendeskripsikan gaya bahasa (Style) literatur anak bergenre dongeng, teknik penerjemahan yang digunakan, dan kualitas terjemahan dongeng tersebut. Metode penelitian yang digunakan adalah metode penelitian deskriptif kualitatif dengan studi kasus terpancang. Kemudian objek penelitiannya adalah dua dongeng Disney dwibahasa berjudul Cinderella: My Bedtime Story dan Tinker Bell and the Great Fairy Rescue. Hasil dari penelitian menunjukkan bahwa berdasarkan jenis leksis, struktur kelompok nomina, dan struktur klausanya, dongeng pertama berada pada kontinum gaya bahasa cenderung lisan dan dongeng kedua berada pada kontinum gaya bahasa lisan tulis. Beberapa teknik penerjemahan yang digunakan pada kedua dongeng meliputi teknik kesepadanan lazim, variasi, amplifikasi, reduksi, transposisi, modulasi, dan kompresi linguistik. Peggunaan teknik tersebut mampu mempertahankan gaya bahasa dongeng dan menghasilkan terjemahan yang akurat dan terbaca, walaupun tingkat keberterimaan kurang.
\end{abstract}

Kata kunci: gaya bahasa, literatur anak, dongeng, teknik penerjemahan, kualitas terjemahan.

\section{Pendahuluan}

Kesadaran untuk membaca mendorong para orang tua untuk membiasakan anakanak membaca sejak dini. Sehingga kesempatan ini disambut baik oleh para penulis dan penerbit buku untuk menerbitkan buku untuk anak-anak. Saat ini, buku-buku untuk anak banyak didominasi dengan buku-buku cerita, baik buku cerita bergambar atau tidak. Misalnya seri fabel kancil, cerita si lebah madu, legenda, atau cerita rakyat. Biasanya dalam cerita tersebut disisipkan nilai-nilai moral yang berkaitan dengan 
kehidupan sehari-hari atau isu-isu tertentu seperti isu tentang bisnis syariah sebagaimana cerita yang sditulis oleh Fita Chakra berjudul Dimas dan Sepatu Pinjamannya (2013). Maka tidak heran jika dikatakan bahwa buku dapat mempengaruhi perkembangan anak. Sebagaimana diungkapkan oleh Wohlgemuth (1998) bahwa buku memiliki peranan penting dalam mempengaruhi dan memanipulasi perkembangan anak.

Mudahnya pertukaran informasi mancanegara juga sangat mempengaruhi peredaran jenis literatur anak dalam negeri. Hal ini berdampak pada semakin menjamurnya buku-buku cerita terjemahan yang tidak jarang mendominasi penjualan buku cerita anak di toko-toko besar. Ditambah lagi pada umumnya anak-anak lebih mengenal cerita-cerita seperti Cinderella, Sleeping Beauty, Kisah peri Tinkerbell, atau kisah putri kerajaan Tale of Two Sisters, sehingga buku dongeng ini akan lebih meledak di pasaran. Maka tidaklah mengherankan jika saat ini banyak di antara penerjemah atau penerbit yang melirik buku-buku dongeng mancanegara ini untuk diterjemahkan ataupun disadur dan disajikan dalam dongeng dwibahasa dilengkapi gambar yang menarik.

Melihat fenomena tersebut, tidaklah mengherankan jika penerjemahan teks anak menjadi pilihan penerjemah. Hal ini sangat kontras dengan persepsi awal bahwa menulis atau menerjemahkan teks anak memiliki nilai yang lebih rendah dari pada teks untuk dewasa. Bahkan banyak yang menjadikan pekerjaan menulis teks untuk anak sebagai batu loncatan awal karir seseorang di dunia penerjemahan.

Penerjemahan untuk anak yang sering kali dipandang sepele dapat mengakibatkan salah interpretasi. Hal ini disebabkan penerjemahan teks anak bukan saja sekedar menulis ulang dalam bahasa sasaran pada waktu, tempat, dan budaya yang berbeda. Penerjemahan untuk anak juga meliputi sikap penerjemah terhadap bahasa sasaran dan budaya yang dipakai oleh pembaca sasaran (Stolze, 2003). Oleh karenanya seorang penerjemah harus memperhatikan aturan-aturan dalam menerjemahkan teks untuk anak.

Sebagaimana diungkapkan Purtineen (1998) dalam penelitiannya bahwa salah satu aspek terpenting dalam literatur anak adalah keterbacaan teks yang ditentukan oleh kompleksitas struktur kebahasaan. Tidak hanya itu, keterbacaan teks anak juga mencakup kemudahan untuk diceritakan kembali, mengingat buku anak sering kali dibaca keras baik oleh orang tua maupun anak-anak. 
Pendapat Purtineen diatas senada dengan pendapat Richard et. al. yang dikutip oleh Nababan (2008) bahwa keterbacan suatu teks tergantung pada panjang rata-rata kalimat, jumlah kata baru, dan kompleksitas gramatika yang digunakan dalam suatu bahasa. Oleh karena itu, seorang penerjemah literatur anak hendaknya lebih cermat dalam menerjemahkan kalimat-kalimat yang panjang dengan struktur kebahasaan yang kompleks sesuai dengan kemampuan berbahasa anak.

Berikut beberapa contoh kalimat yang perlu diperhatikan penerjemah agar aspek keterbacaan dalam literatur anak dapat dicapai tanpa mengesampingkan aspek keakuratan, keberterimaan, dan gaya penulisan teks untuk anak-anak:

\section{BSu: It was a magnificent Sapphire}

ring.

\section{BSa: Sebuah cincin yang indah.}

Berdasarkan kalimat diatas dapat kita lihat bahwa pada Bahasa sumber (BSu) penulis mengungkapkan idenya dengan struktur kalimat lengkap (klausa simplek). Terdapat penambahan pronomina ' $I t$ ' yang mengacu pada cincin safir. Sementara itu pada Bahasa Sasaran (BSa) struktur tersebut menjadi bergeser. Penulis merubah strukturnya menjadi klausa minor yang terdiri dari kelompok nomina saja. Keputusan untuk merubah struktur seperti yang dilakukan penulis dapat dibenarkan dalam penerjemahan anak demi ketersampaian pesan dan keterbacaan teks. Dengan kata lain penulis buku dwibahasa maupun penerjemah teks anak memiliki kebebasan yang luas untuk memanipulasi teks anak tersebut (Shavit, 1986: hal. 112).

Dalam teks naratif seringkali terdapat kalimat kompleks karena jenis teks ini menceritakan urutan kejadian yang membentuk cerita utuh. Demikian pula penulisan teks naratif untuk anak. Akan tetapi teks semacam ini mungkin akan membingungkan bagi anak ataupun orang tua sebagai pembaca dongeng. Seperti pada contoh kalimat berikut

BSu: She is thrilled to see a real fairy like Tinkerbell ||and takes her to her bedroom Ilas Vidia watches in horror.

BSa: Ia sangat senang melihat peri sungguhan, Tinkerbell. Ia lalu membawa Tinker Bell ke kamarnya, sementara Vidia menyaksikan dengan ketakutannya.

Kalimat bahasa sumber (BSu) pada teks tersebut memiliki struktur kalimat kompleks dengan tiga proses yang terjadi. Kemudian pada kalimat bahasa sasaran (BSa) kalimat kompleks tersebut menjadi bergeser menjadi kalimat simpleks dan kompleks. 
Pergeseran seperti ini tentu saja bukan kebetulan semata. Penerjemah tentu memiliki alasan khusus mengapa bahasa sasarannya diterjemahkan demikian.

Teks bergenre cerita naratif memiliki fungsi sosial untuk menghibur pembaca dengan penuturan berbagai pengalaman yang aktual yang mengarah pada suatu permasalahan dan berujung pada penyelesaian masalah yang muncul (Gerot \& Wignell, 1995:204). Oleh karenanya penulis teks anak tetap dituntut untuk menuliskan cerita tersebut dalam teks yang dramatis tetapi tetap mengedepankan kemampuan berbahasa anak. Contohnya ada pada kalimat berikut:

BSu: Red with rage, Tinker Bell decides to show herself to Lizzie's father.

BSa: Tinker Bell marah, ia pun memutuskan untuk menunjukkan diri pada ayah Lizzi.

Pada kalimat ini dapat dilihat bahwa penulis sengaja memilih ungkapan 'Red with rage' sebagai sirkumstansi dalam kalimat tersebut. Pada teks BSa, ungkapan tersebut diterjemahkan menjadi klausa 'Tinker Bell Marah'.

Fenomena penerjemahan teks anak semacam ini menarik untuk dikaji karena teks anak memiliki gaya bahasa yang unik. Selain itu dalam dunia penerjemahan, penerjemahan teks anak seringkali disebut terjemahan yang disederhanakan (Simplified translation). Tentunya baik penulis maupun penerjemah memiliki tantangan yang besar dalam menghasilkan tulisan yang layak dibaca untuk anak-anak dan tetap pada koridor gaya bahasa literatur anak.

Penelitian pada penerjemahan teks anak ini akan dilakukan pada dua dongeng dwibahasa, yaitu Cinderella: Kisah Pengantar Tidur dan Tinker Bell and the Great Fairy Rescue yang ditulis oleh Grace Lim Pineda dari The Walt Disney Co. Southeast Asia Pte. Ltd. Cerita ini kemudian diterjemahkan dan dicetak dalam dua bahasa oleh PT. Adinata Melodi Kreasi pada tahun 2013 dengan tujuan mendeskripsikan gaya bahasa (Style), teknik penerjemahan, dan kualitas terjemahannya. Penelitian ini dilihat dari sudut pandang Lingustik Sistemik Fungsional, yang mengidentifikasi gaya bahasa berdasarkan penggunaan leksis, struktur kelompok nomina, dan struktur klausanya.

\section{Teori dan Metodologi Penelitian}

Penelitian ini dirancang dalam bentuk studi kasus terpancang karena fokus penelitian sudah ditentukan sebelumnya. Variabel dalam penelitian semacam ini merupakan suatu kesatuan yang berkesinambungan dan bukan merupakan hubungan 
sebab-akibat sehingga hasilnya terikat pada satu konteks situasi saja (Lincoln \& Guba, 1985).

Penelitian ini juga termasuk dalam jenis penelitian deskriptif kualitatif karena data berasal dari fenomena penerjemahan teks anak terkait dengan gaya bahasa yang digunakan. Hal ini sesuai dengan pendapat Bungin (2009) yang menyatakan bahwa penelitian deskriptif kualitatif bertujuan untuk menggambarkan dan meringkas berbagai kondisi, situasi, atau fenomena realitas sosial yang ada. Kemudian realitas tersebut ditarik ke permukaan sebagai ciri, karakter, sifat, model, tanda, atau gambaran tentang situasi, kondisi, ataupun fenomena tertentu.

Data yang digunakan adalah data primer yang berupa teks dongeng anak dwibahasa dan informasi dari informan tentang kualitas terjemahan dongeng. Teknik sampling yang digunakan adalah teknik purposive sampling, yaitu teknik pengambilan sampel berdasarkan karakteristik tertentu (Sugiyono, 2013). Setelah menentukan sampelnya, data dikumpulkan melalui analisis dokumen, kuesioner, dan wawancara. Selanjutnya data yang terkumpul diolah menggunakan teknik analisis isi (Content analysis) Spradley (1980) yang terdiri dari empat tahapan. Tahapan tersebut adalah analisis domain, analisis taksonomi, analisis komponensial, dan analisis tema budaya untuk melihat pola nilai kultural dibalik data.

\section{Hasil Penelitian dan Pembahasan}

\section{Leksis, Kelompok Nomina, dan Klausa}

Berdasarkan penelitian, leksis yang digunakan dalam dongeng BSu Cinderella: My Bedtime Story berjumlah 322 leksis dengan pembagian 317 leksis berjenis kongruen dan sisanya 4 leksis berjenis inkongruen. Berbeda dengan teks BSa yang hanya menggunakan 314 leksis yang terbagi dalam 312 leksis kongruen dan 2 leksis inkongruen. Teks BSu dan BSa memiliki jumlah leksis yang berbeda karena adanya pergeseran dalam proses penerjemahannya.

Diantara pergeseran leksis yang terjadi pada dongeng ini adalah kata 'a cry' diterjemahkan menjadi 'berseru' yang relitas fisiknya merupakan suatu proses dan dinyatakan dalam realitas simbol kata kerja (verba). Pergeseran berikutnya adalah Kata 'to honor' merupakan proses yang direalisasikan dalam realitas simbol yang sesuai yaitu kata kerja tetapi dalam teks bahasa sasarannya penerjemah memilih menggunakan 
kata 'penghargaan' yang merupakan suatu bentuk proses yang dinominalisasi sehingga realitas simbolnya menjadi kata benda (Noun).

Selanjutnya pada dongeng kedua berjudul Tinker Bell and the Great Fairy Rescue, dalam teks bahasa sumbernya terdapat 479 leksis dan 12 leksis diantaranya merupakan leksis yang bersifat inkongruen. Sedangkkan dalam bahasa sasarannya leksis yang digunakan tercatat sebanyak 460 leksis yang terbagi menjadi 451 leksis kongruen dan 9 leksis inkongruen.

Dalam teks dongeng ini juga terdapat pergeseran leksis baik dari leksis kongruen menjadi inkongruen maupun sebaliknya. Sebagai contoh adalah leksis inkongruen 'look' dalam kelompok nomina 'a closer look' diterjemahkan menjadi leksis kongruen 'melihat'. Kemudian leksis kongruen 'it was raining...' diterjemahkan menjadi leksis inkongruen 'hujan'.

Analisis selanjutnya pada bentuk kelompok nomina kedua dongeng yang terbentuk dari unsur deictic (deiktik), numeric (numeralia), ephitet (penjenis), classifier (pendeskripsi), dan qualifier (penjelas). Pada dongeng Cinderella: My Bedtime Story terdapat 41 kelompok nomina yang terbagi dalam 35 struktur pre-modifier+thing, 5 struktur pre-modifier+thing+post-modifier, dan 1 struktur thing+post-modifier. Sedangkan pada teks BSa, jumlah kelompok nomina tersebut berkurang menjadi 32 kelompok nomina saja. Berkurangnya kelompok nomina ini disebabkan oleh pergeseran akibat perbedaan tata bahasa. Agar lebih jelas, bentuk kelompok nomina pada dongeng Cinderella dapat dilihat pada tabel berikut.

\begin{tabular}{|c|c|c|c|c|}
\hline $\begin{array}{l}\text { Kelompok Vomina } \\
\text { Pre-Modificr }\end{array}$ & 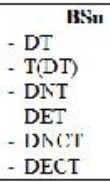 & $\begin{array}{c}. \mathrm{ml} . \\
26 \\
2 \\
1 \\
2 \\
2 \\
2 \\
\end{array}$ & $\begin{array}{l}\text { HSa } \\
\text { - DNT } \\
\text { - NT }\end{array}$ & $\begin{array}{c}. \mathbf{m l} . \\
1 \\
1\end{array}$ \\
\hline $\begin{array}{l}\text { Pre } \\
\text { Mndifier | Thing | Post- } \\
\text { Modifier }\end{array}$ & $\begin{array}{l}\text { NTQ } \\
\text { - DTQ } \\
\text { DCTQ }\end{array}$ & $\begin{array}{l}2 \\
? \\
1\end{array}$ & $\begin{array}{l}\text { NTQ } \\
\text { - VTCD }\end{array}$ & $\begin{array}{l}2 \\
1\end{array}$ \\
\hline Thingַ+Post Modifier & $\mathrm{T}(\mathrm{T}) \mathrm{O}$ & 1 & $\begin{array}{l}\text { TD } \\
- \text { TC } \\
\text { TO } \\
- \text { TNCD } \\
- \text { TCQ } \\
\text { TOD } \\
\text { - T(T)Q }\end{array}$ & $\begin{array}{c}13 \\
5 \\
3 \\
1 \\
1 \\
2 \\
2 \\
1 \\
\end{array}$ \\
\hline
\end{tabular}


Sebagaimana dongeng sebelumnya, penggunaan kelompok nomina pada dongeng Tinker Bell and the Great Fairy Rescue 58 kelompok nomina dengan pembagian 44 struktur pre-modifier+thing, 11 struktur pre-modifier+thing+post-modifier, dan 4 kelompok nomina thing+post-modifier. Berikut disajikan tabel bentuk-bentuk kelompok nomina yang ada pada dongeng Tinker Bell.

\begin{tabular}{|l|c|l|c}
\hline \multicolumn{1}{|c|}{ Struktur Klausa BSu } & Jumlah & \multicolumn{1}{|c}{ Struktur Klausa BSa } & Jumlah \\
\hline Simpleks & 15 & Simpleks & 13 \\
\hline Hipotaktik:Enhansi & 3 & Hipotaktik:Enhansi & 1 \\
\hline Hipotaktik: Projeksi-Idea & 1 & Klausa minor & 1 \\
\hline Parataktik: Projeksi-Lokusi & 14 & Hipotaktik:Enhansi & 3 \\
\hline Parataktik: Projeksi-Idea & 1 & Hipotaktik:Projeksi-Idea & 1 \\
\hline Parataktik: Ekstensi & 1 & Parataktik: Projeksi-Lokusi & 14 \\
\hline Parataktik: Enharsi & 1 & Parataktik: Projeksi-Icea & 1 \\
\hline Klausa minor & 1 & Parataktik: Ekstensi & 1 \\
\hline & & Parataktik: Enhansi & 1 \\
\hline & & Klausa minor & 1 \\
\hline Jumlah Klausa & 37 & \multicolumn{2}{|c}{} \\
\hline
\end{tabular}

Tabel 4.7. Kelompok nomina dongeng TinkerBell: The Great Fairy Rescue

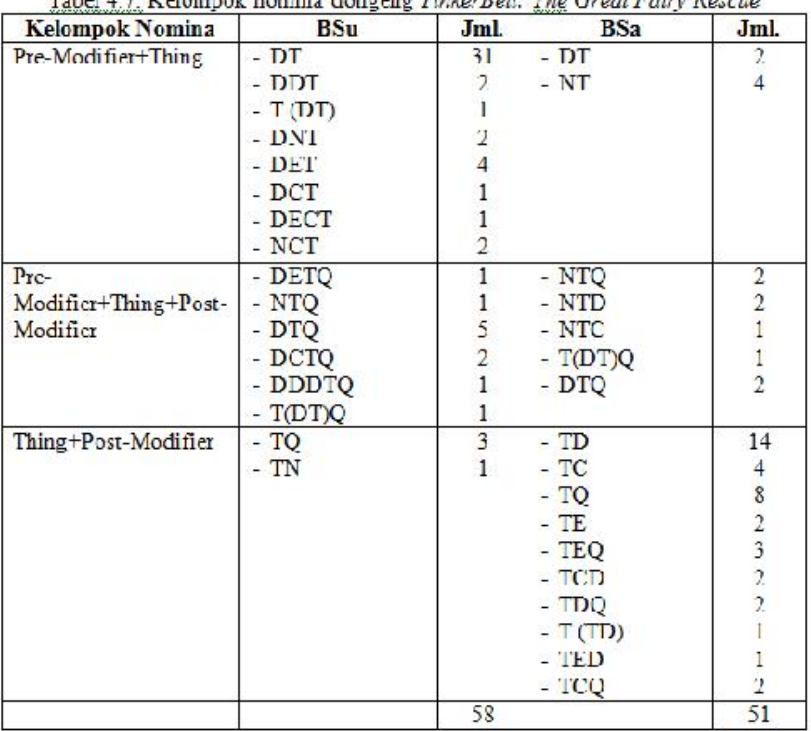


Indikator penentu gaya bahasa selanjutnya adalah bentuk klausa. Dari penelitian yang dilakukan diketahui bahwa pada dongeng Cinderella: My Bedtime Story terdapat 37 klausa. Diantara 37 klausa tersebut didominasi oleh bentuk 17 klausa kompleks parataktik, 4 klausa kompleks hipotaktik, 15 klausa simpleks dan 1 klausa minor. Dalam teks BSa klausa ini diterjemahkan sepadan namun terdapat beberapa klausa yang bergeser diantaranya klausa simpleks menjadi klausa hipotaktik dan klausa minor. Pergeseran ini terjadi akibat perubahan leksis dan kelompok nomina. Agar lebih jelas, struktur klausa dapat dilihat pada tabel berikut.

\begin{tabular}{|c|c|c|c|}
\hline Struktur Klausa BSu & Tumlah & Struklur Klausu BSu & . Inmluh \\
\hline Simpleks & 21 & Simpleks & 21 \\
\hline Simplcks & 1 & Parataktik: Ełsstensi & 1 \\
\hline Hipolaklik: Fnhansi & 4 & Hijodak lik: Frıhbansi & 4 \\
\hline Parataktik: Ekstensi & 9 & Parataktik: Ekstensi & 9 \\
\hline Hipotaktik: Lokusi & 1 & Hipotaktik: Lokusi & 1 \\
\hline Hipotaktik: Lokusi & 1 & Simpleks & 1 \\
\hline Hipotaktik:Ide & 3 & Hipotaktik: Idc & 3 \\
\hline Paralaklik: Fkstensi + & 1 & Sitnjleks: & 1 \\
\hline IIipotaktik: Lnhansi & & Hipotaktik: Enhansi & 1 \\
\hline Parataktik: Enhansi+ & 1 & Simplcks & 1 \\
\hline $\begin{array}{l}\text { Parataktik: Lkstensi } 1 \\
\text { Hijolsk lik : Tcle }\end{array}$ & 1 & $\begin{array}{l}\text { Parataktik: Lkstensi } 1 \\
\text { Hijoliaklik : Tde }\end{array}$ & 1 \\
\hline $\begin{array}{l}\text { Parataktik: Ekstensi + } \\
\text { Paralakkik: Fkstensi }\end{array}$ & 1 & $\begin{array}{l}\text { Parataktik: Ekstensi- } \\
\text { Paralaklik: Fiksterısi }\end{array}$ & 1 \\
\hline Jumlah Klausa & 1.1 & & 46 \\
\hline
\end{tabular}

Sedikit berbeda dengan dongeng Cinderella, klausa pada dongeng Tinker Bell and the Great Fairy Rescue dibentuk dari perpaduan klausa simpleks dan kompleks dalam jumlah yang sama. Pada dongeng ini terdapat 22 klausa simpleks dan 22 klausa kompleks yang memiliki hubungan interdependensi bermacam-macam. Berikut rincian jenis klausa pada dongeng Tinker Bell.

Berdasarkan temuan jumlah leksis, kelompok nomina, dan klausa pada kedua dongeng maka dapat dikatakan bahwa dongeng Cinderella: My Bedtime Story memiliki gaya bahasa yang terletak pada kontinum cenderung lisan. Disisi lain, gaya bahasa dongeng Tinker Bell and the Great Fairy Rescue terletak pada kontinum lisan tulis.

\section{Teknik Penerjemahan}

Teknik penerjemahan ini dianalisis berdasarkan 18 jenis teknik penerjemahan yang digagas Molina dan Albir (2002). Analisis teknik ini dilakukan pada tataran klausa, kelompok nomina, dan leksisnya. 
Dari penelitian yang sudah dilakukan, terdapat klausa yang hanya menggunakan satu teknik penerjemahan. Selain itu ada pula beberapa teknik penerjemahan yang digunakan dalam sebuah klausa. Diantara teknik penerjemahan yang digunakan dalam penerjemahan teks anak ini adalah teknik kesepadanan lazim, variasi, amplifikasi, transposisi, modulasi, reduksi, peminjaman, dan kompresi linguistik. Berikut rekapitulasi penggunaan teknik penerjemahan pada dongeng Cinderella: My Bedtime Story dan TinkerBell: The Great Fairy Rescue.

\begin{tabular}{|lc|c|}
\hline \multicolumn{1}{|c|}{ Teluik Penerjemahan } & $\begin{array}{c}\text { Cinderella } \\
\text { - Kesepadanan I azim }\end{array}$ & $\begin{array}{c}\text { Tinker Bell } \\
16\end{array}$ \\
\hline - Variasi & 16 & 7 \\
\hline - Amplifikasi & 10 & 19 \\
\hline - Transposisi & 4 & 12 \\
\hline - Modulasi & - & 6 \\
\hline - Reduksi & 3 & 6 \\
\hline - Peminjaman & - & 1 \\
\hline - Kompresi Linguistik & 4 & - \\
\hline
\end{tabular}

Dari tabel di atas diketahui bahwa teknik kesepadanan lazim merupakan teknik yang paling sering digunakan pada kedua dongeng karena teks anak cenderung sederhana dan terjemahannya menggunakan padanan yang lazim diketahui anak. Pada dasarnya tidak ada kata dalam dua bahasa yang dapat diterjemahkan sama, sehingga proses penerjemahannya hanya mencari padanan terdekat dan lazim digunakan (Yinhua, 2011).

\section{Kualitas Terjemahan}

Poin penilaian kualitas terjemahan ini mengacu pada tiga komponen kualitas dalam terjemahan yaitu keakuratan (Accuracy), keberterimaan (Acceptibility), dan keterbacaan (Redibility). Penilaian aspek keakuratan didasarkan pada kesepadanan teks BSu dan BSa. Konsep kesepadanan ini mengarah pada kesamaan isi atau pesan antar keduanya (Nababan, 2012). Dalam penelitian ini, kedua dongeng memiliki tingkat keakuratan yang baik. Dari skala 1-3 nilai keakuratan dongeng Cinderella mencapai 2,7, sedangkan dongeng Tinker Bell nilai keakuratannya mencapai 2,5. Aspek penilaian berikutnya adalah aspek keberterimaan. Istilah keberterimaan merujuk kesesuaian teks terjemahan dengan kaidah-kaidah, norma, dan budaya yang berlaku dalam bahasa sasaran (Nababan, 2012). Terkait aspek ini, kedua dongeng memiliki nilai keberterimaan yang sama, yaitu 2,4.

Aspek yang terakhir adalah keterbacaan. Aspek ini terkait dengan kegiatan membaca teks bahasa sasaran. Pada aspek ini kedua dongeng juga memiliki nilai yang 
sama yaitu 2,7. Untuk melihat prosentase kualitas terjemahan kedua dongeng dapat dilihat pada tabel berikut.

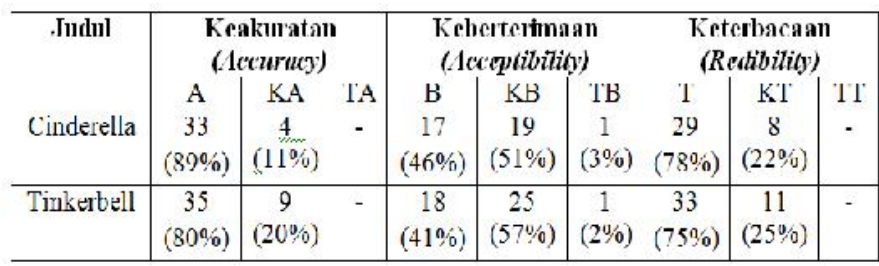

\section{Pembahasan}

\section{Gaya Bahasa Dongeng Anak}

Gaya bahasa atau style dapat diartikan sebagai register atau variasi bahasa berdasarkan penggunaannya (Santosa, 2003: hal. 47). Dalam hal ini gaya bahasa suatu teks tidak hanya didasarkan pada pilihan katanya saja tetapi juga penggunaan struktur dan tekstur teks yang terbatas pada konfigursi makna berdasarkan medan, pelibat, dan sarananya. Misalnya saja teks literatur anak yang memiliki fitur unik dan diperuntukkan bagi pembaca anak-anak pada umumnya ditulis dengan bahasa yang sederhana. Konfigurasi makna dalam literatur anak pun dapat berbeda-beda tergantung fungsi atau genre literatur anak tersebut.

Dalam teks dongeng seperti dongeng Cinderella dan Tinkerbell yang merupakan kisah fantasi, penulis menggunakan leksis yang bersifat kongruen meskipun leksis inkongruen juga masih digunakan. Leksis ini kemudian membentuk kelompok nomina simlpleks yang berfungsi menggambarkan setiap entitas secara jelas. Selanjutnya cerita disusun dalam susunan klausa yang cenderung simpleks atau klausa kompleks dengan proses yang tidak tumpang tindih. Konfigurasi makna semacam ini akan menunjang keterbacaan teks mengingat teks literatur anak tidak hanya dibaca oleh anak tetapi juga dibacakan oleh orang tua (Puurtinen, 1998). Ditambah lagi kemampuan membaca komprehensif anak yang masih rendah mengharuskan penulis maupun penerjemah menuangkan tulisan berdasarkan sudut pandang anak (Nurgiyantoro, 2004).

Dongeng Cinderella: My Bedtime Story mengisahkan pertemanan antara manusia dengan hewan. Mereka kemudian terlibat dalam percakapan untuk menyelesaikan permasalahan yang tengah dihadapi Cinderella. Walaupun cerita ini ditulis dengan bahasa sangat sederhana dan alur cerita yang cukup singkat tetapi tetap mengusung nilai-nilai universal yang ditujukan kepada anak-anak seperti rasa tolong menolong dan penghargaan atas jasa. Pun dalam teks bahasa sasarannya, nilai-nilai 
moral tersebut dapat tersampaikan karena memiliki konfigurasi makna yang mirip yaitu ragam gaya bahasa cenderung lisan.

Dongeng Tinkerbell: The Great Fairy Rescue merupakan cerita fantasi yang menceritakan tentang kesetiakawanan antar peri. Seperti teks dongeng sebelumnya, secara umum dongeng Tinkerbell ini juga dikisahkan dengan leksis yang bersifat konkrit. Hanya saja dalam teks ini penulis menyisipkan elemen-elemen linguistik yang bersifat abstrak seperti penggunaan metafora 'red with rage' dan leksis inkongruen seperti 'journey', 'discovery', dan 'disaster'. Meskipun bersifat abstrak, leksis-leksis ini dapat memperindah cerita serta menstimulasi emosi dan imajinasi anak. Struktur kelompok nominanya juga dibuat sedikit lebih kompleks tetapi tetap bersifat definite sehingga penggambaran tokoh dan suasana menjadi lebih jelas. Kondisi ini kemudian menyebabkan klausa menjadi lebih panjang dan kompleks. Namun demikian kompleksitas tersebut tetap menghasilkan cerita yang memiliki ragam bahasa lisan yang diwujudkan dalam tulisan.

Baik ragam gaya bahasa cenderung lisan maupun lisan tulis umumnya menggunakan leksis yang lebih konkrit sehingga bahasa terkesan lebih ringan dan encer. Sistim klausanya yang digunakan cenderung lebih kompleks untuk menunjukkan rangkaian kejadian yang membentuk suatu cerita. Sedangan sistim grupnya (nomina, verba, dan adjuct) dinyatakan dengan simpleks karena lebih jelas entitas yang dirujuk. Literatur anak banyak ditulis dalam kontinum ragam gaya bahasa lisan-tulis hingga lisan. Hal ini disesuaikan dengan kemampuan komunikasi anak yang masih terbatas sesuai usianya.

\section{Teknik penerjemahan dan dampaknya pada Gaya Bahasa Dongeng Anak}

Menulis literatur anak selalu dianggap lebih mudah dari pada menulis literatur untuk orang dewasa. Namun faktanya menulis untuk anak-anak merupakan hal yang cukup riskan karena penulis, yang notabene adalah seorang dewasa, harus menuangkan ide pada level kemampuan dan gaya bahasa anak. Tidak hanya penulis, penerbit, dan pemerhati buku anak-anak harus mampu mengontrol peredaran buku anak, mengingat anak-anak belum mampu memilah buku apa yang baik untuk mereka (Wolgemuth, 1998).

Demikian juga dalam hal penerjemahan teks anak, penerjemah harus lebih memperhatikan berbagai aspek termasuk karakteristik teks anak aspek komunikatifnya. 
Dengan memperhatikan aspek komunikatif anak dapat tercipta teks terjemahan yang efektif (Wolgemuth, 1998).

Menerjemahkan teks anak yang komunikatif dapat dicapai dengan mempertahankan gaya bahasa yang digunakan dalam teks anak itu sendiri. Dalam kegiatan penerjemahan, pemertahanan semacam ini ditentukan oleh proses penerjemahan. Pada tahap inilah seorang penerjemah sering kali mengalami dilema pengambilan keputusan yang melibatkan penggunaan metode dan teknik penerjemahan (Machali, 2009). Pemilihan teknik yang tepat menentukan hasil terjemahan. Molina dan Albir (2002) menyebutkan bahwa teknik penerjemahan merupakan langkah nyata para penerjemah dalam mengatasi masalah yang mungkin muncul dalam setiap proses penerjemahan termasuk masalah pemertahanan gaya bahasa teks anak.

Berdasarkan penelitian terhadap dua dongeng anak berjudul Cinderella: My Bedtime Story dan TinkerBell: The Great Fairy Rescue terdapat beberapa teknik penerjemahan yang digunakan penerjemah dan masing-masing teknik memiliki dampak yang berbeda sesuai konteksnya. Diantara teknik penerjemahan yang digunakan adalah teknik kesepadanan lazim, variasi, amplifikasi, transposisi, modulasi, reduksi, kompresi linguistik, dan peminjaman.

Teknik kesepadanan lazim merupakan teknik yang paling dominan digunakan. Teknik ini merupakan prosedur pengalihan pesan dengan mencari padanan yang terdekat dengan teks BSu. Penggunaan teknik ini hampir tidak menyebabkan perubahan yang signifikan terhadap bentuk gaya bahasa yang digunakan dalam kedua dongeng. Teknik ini berdampak pada penambahan atau pengurangan leksis, perubahan bentuk kelompok nomina, dan pada dongeng Tinker Bell terdapat perubahan bentuk klausa.

Teknik variasi yang digunakan pada dua teks dongeng ini merupakan teknik penerjemahan dengan merubah tona tekstual dalam bahasa sumber menjadi berbagai tona tekstual yang berbeda dalam bahasa sasaran. Teknik ini lazim digunakan pada adaptasi novel ke dalam teks anak sehingga bahasa yang disajikan sesuai untuk usia pembaca anak (Molina \& Abir, 2002). Teknik variasi yang terjadi dalam teks BSu dongeng Cinderella berupa variasi terjemahan subjek 'I' menjadi 'aku', 'you' menjadi 'kau' atau 'kamu', dan 'we' menjadi 'kami'. Penerapan teknik ini tidak merubah gaya bahasa cenderung lisan yang digunakan karena kata sapaan 'aku' dan 'kau' 
menunjukkan kedekatan antar tokoh serta mengesankan gaya bahasa yang lebih encer. Kemudian kata 'kami’ memiliki kesan yang lebih sopan.

Tidak berbeda dengan teks dongeng sebelumnya, pada teks dongeng yang kedua, teknik variasi diterapkan pada beberapa data, meskipun jumlahnya tidak sebanyak penggunaan teknik variasi pada dongeng sebelumnya. Perubahan yang terjadi akibat teknik ini hampir sama dengan teks sebelumnya, hanya saja kata ganti orang ketiga seperti 'he' dan 'she' diterjemahkan menjadi 'ia'. Hal ini dilakukan untuk mempertahankan gaya bahasa lisan tulis yang diterapkan penulis bahasa sumber.

Teknik amplifikasi merupakan prosedur pengalihan pesan $\mathrm{BSu}$ dengan menambahkan informasi ekssplisit sehingga tidak terjadi tumpang tindih makna pada BSa. Pada dongeng pertama teknik amplifikasi banyak digunakan untuk menambahkan informasi terkait proses. Sedangkan pada dongeng kedua, teknik amplifikasi banyak digunakan untuk memperjelas pronomina yangmenunjukkan setiap tokohnya. Sebagai dampaknya informasi lebih tersampaikan dengan baik. Walaupun terdapat penambahan atau eksplisitasi pesan $\mathrm{BSu}$, hal ini tidak mempengaruhi gaya bahasa teks.

Teknik transposisi ini dilakukan dengan cara mengubah kategori gramatika teks bahasa sumber ke dalam ketegori gramatika teks bahasa sasaran. Perubahan ini dimaksudkan agar teks terjemahan menjadi sepadan dan berterima. Penggunaan teknik ini sangat berpotensi merubah gaya bahasa suatu teks karena perubahan dapat terjadi pada level atau kategori kata (Catford, 1965). Misalnya pada dongeng Cinderella terdapat klausa simpleks 'It was a magnificent Sapphire ring' yang diterjemahkan menjadi klausa minor terbentuk dari kelompok nomina 'Sebuah cincin yang indah'. Akan tetapi perubahan ini tidak terjadi secara masif pada kedua dongeng sehingga tidak dapat dikatakan merubah gaya bahasa.

Hal yang sama terjadi pada teknik modulasi. Teknik ini merupakan prosedur penerjemahan dengan merubah sudut pandang, fokus, maupun kategori kognitif bahasa sasaran. Teknik ini dapat bersifat wajib atau manasuka (Machali, 2009). Teknik ini hanya ditemukan pada teks Tinker Bell karena klausanya lebih kompleks dan terdapat beberapa klausa yang memerlukan pengubahan sudut pandang. Perubahan ini lebih bersifat manasuka tetapi dapat menciptakan gaya bahasa yang sederhana. Prosedur penerjemahan semacam ini boleh dilakukan karena menurut Shavit (1981) penerjemah 
teks anak memiliki kebebasan yang mutlak dalam memanipulasi teks bahasa sasaran tetapi tidak mengesampingkan nilai yang terkandung dalam teks bahasa sumbernya.

Teknik reduksi atau penghilangan informasi pada BSu dapat dilakukan asalkan tidak menyebabkan distorsi makna pada BSa. Dalam konteks penerjemahan teks anak, reduksi dapat dilakukan agar anak lebih mudah memahami suatu teks dank arena sebagaimana disebutkan sebelumnya penerjemah memiliki kebebasan memanipulasi teks agar terjemahan tetap akurat, berterima, dan terbaca dengan baik. Penggunaan teknik ini juga sangat cocok diterapkan untuk mempertahankan gaya bahasa teks anak yang sederhana.

Teknik berikutnya yang digunakan pada penerjemahan teks dongeng anak adalah teknik kompresi linguistik. Teknik ini hanya digunakan pada dongeng Cinderella, karena teks tersebut banyak mengandung ujaran. Berbeda dengan teks Tinker Bell yang bersifat narasi dan tidak terdapat ujaran, sehingga teknik ini tidak digunakan. Penggunaan teknik ini berdampak pada efektifitas penyampaian pesan sehingga karakteristik gaya bahasa anak dapat dipertahankan.

Teknik terakhir yang ditemukan pada proses penerjemahan dongeng ini adalah teknik peminjaman. Teknik peminjaman dilakukan jika konsep dalam BSu tidak terdapat padanannya dalam BSa. Teknik ini ditemukan satu kali pada teks Tinker Bell untuk menerjemahkan konsep 'oak tree'. Dalam konteks cerita ini, penggunaan teknik ini sama sekali tidak memberikan dampak tertentu pada gaya bahasa yang digunakan.

\section{Kualitas Terjemahan Dongeng Anak}

Penilaian kualitas terjemahan penting dilakukan sebagai kontrol penerjemah untuk menghasilkan terjemahan yang sesuai untuk anak. Sebagimana diungkapkan Puurtinen (1998) bahwa penilaian terhadap terjemahan teks anak sangat penting untuk melihat kelaikan isi, kesesuaian level teks, dan keberterimaan teks pada budaya BSa. Hal ini sesuai dengan konsep penilaian kualitas terjemahan yang digagas Nababan (2012), yaitu penilaian kualitas berdasarkan aspek keakuratan, keberterimaan, dan keterbacaan.

Pada aspek keakuratan kedua teks memiliki nilai yang hampir sama, hanya terpaut 0,2 poin saja. Dengan demikian dapat dikatakan kedua teks memiliki tingkat keakuratan yang baik. Faktor utama yang mendukung tingkat keakuratan teks terjemahan kedua dongeng adalah penggunaan teknik yang tepat, yaitu teknik 
kesepadanan lazim. Data yang diterjemahkan dengan teknik tersebut memiliki nilai akurasi yang tinggi. Teknik kesepadanan lazim membuat gaya bahasa dongeng dapat dipertahankan sesuai dengan gaya bahasa teks BSu.

Pada aspek keberterimaan, kedua terjemahan dinilai kurang berterima. Penilaian ini didasarkan pada kesalahan penulisan seperti penggunaan tanda baca dan penggunaan huruf kapital. Beberapa data juga diidentifikasi kurang berterima karena penggunaan leksis yang kurang tepat seperti pemadanan relative clause.

Aspek keterbacaan dalam penerjemahan berkaitan erat dengan kemudahan teks BSa untuk dibaca. Pada konteks penerjemahan teks anak, kriteria penilaian keterbacaan ditambah dengan penilaian kemudahan teks terjemahan untuk dibacakan kembali pada anak (Puurtinen, 1998). Berdasarkan para resonden, kedua dongeng memiliki tingkat keterbacaan yang tinggi, akan tetapi teks Tinker Bell lebih mudah untuk dibacakan kembali.

Beberapa teknik yang digunakan dalam penerjemahan teks dongeng Cinderella dan Tinkerbell juga membantu kualitas keterbacaan teks ini. Diantara beberapa teknik tersebut adalah teknik amplifikasi dan variasi. Penggunaan teknik amplifikasi dengan eksplisitasi teks menambah pemahaman bagi pembaca sasaran. Penggunaan teknik variasi juga meberikan keleluasaan penerjemah mengatur tona tekstual dalam teks BSa sehingga teks terkesan lebih natural.

\section{Simpulan}

Teks anak khususnya yang bergenre dongeng pada umumnya memiliki leksis yang konkrit dan sedikit abstraksi. Struktur teks pun dibentuk secara sederhana. Adapun klausa kompleks yang digunakan tetap dalam level yang sesuai untuk anak. Oleh karena itu gaya bahasa dongeng anak terletak pada kontinum gaya bahasa antara lisan hingga hingga lisan tulis.

Penggunaan teknik penerjemahan secara tepat seperti penggunaan teknik kespadanan lazim, amplifikasi, dan variasi dapat mempertahankan gaya bahasa teks anak. Ketepatan penggunaan teknik tersebut juga sangat berdampak pada tingginya nilai keakuratan dan keterbacaan. Hanya saja pada konteks penerjemahan dua dongeng anak berjudul Cinderella: My Bedtime Story dan TinkerBell: The Great Fairy Rescue ini, keduanya memiliki nilai keberterimaan yang kurang baik. Kurangnya nilai 
keberterimaan ini disebabkan oleh kaidah penulisan dan penggunaan leksis yang kurang tepat.

\section{Referensi}

Bungin, B. (2005). Anlisis penelitian data kualitatif. Jakarta: Raja Grafindo Persada.

Catford. (1980). A linguistic theory of translation. Great Britain: Oxford University Press.

Chakra, F. (2013). Dimas dan sepatu pinjamannya. Jakarta : Grasindo.

Lincoln, S. Y., \& Guba, E.G. (1985). Naturalistic inquiry. USA: SAGE publication.

Machali, R. (2009). Pedoman bagi penerjemah. Bandung: KAIFA PT. Mizan Pustaka.

Molina, L., \& Albir, A.H. (2002). Translation technique and revisited: A dynamic and Functional Approach. in Meta: Translator's Journal. XLVII, 4.

Nababan, M.R. (2008). Teori menerjemah bahasa Inggris. Yogyakarta: Pustaka Pelajar.

Nababan, M.R., dkk. (2012). Pengembangan model penilaian kualitas terjemahan. Kajian Linguistik dan Sastra, Vol. 24, No. 1, Juni 2012: 39-57.

Nurdiyantoro, B. (2004). Sastra Anak : Persoalan Genre. Jurnal Humaniora, Vol. 16 (no. 2), Juni 2004 : 107-122.

Pineda, G.L. (2013). Cinderella. Jakarta: PT. Adinata Melodi Kreasi. Melodi Kreasi. (2013). Tinker bell and the great fairy rescue. Jakarta: PT. Adinata

Puurtinen, T. (1998). "Syntax, readibility, and ideology in children's literature", Meta: Translators' Journal, vol. 43 (no.4), 1998, p. 524-533.

Santosa, R. (2003). Semiotika sosial. Surabaya: Pustaka Eureka dan JP Press.

Shavit, Z. (1986). Poetics of children's literature. London: The University of Georgia Press.

(1981). Translation of childrens's literature as a function of its position in the literary polysystem. Jurnal. Poetics Today, Vol. 2 No. 4 Translation Theory and Intercultural Relation (Summer-Autum, 1981) pp. 171-179.

Spradley, P.J. (1980). Participant observation. New York: Macalester College. 
Stolze, R. (2003). Translating for children-world view or pedagogics?, Meta:

Translators' Journal, vol 48 (no.1-2), 2003, p. 208-221.

Sugiyono. (2013). Memahami penelitian kualitatif. Bandung: cv. Alfabeta.

Sutopo, H. B., (2002). Metodologi penelitian kualitatif. Surakarta: Sebelas Maret University Press.

Sutopo, H.B. (2006). Penelitian kualitatif: dasar teori dan terapannya dalam penelitian. Surakarta: Universitas Sebelas Maret.

Wohlgemuth, G.T. (1998). Children's literature and its translation: an overview. University of Surrey. http://www.seas.ohio.edu, di akses pada tanggal 7 Februari 2014. 